\title{
CASE-STUDY ANALYSIS OF CONCRETE LARGE-PANEL APARTMENT BUILDING AT PRE- AND POST LOW-BUDGET ENERGY-RENOVATION
}

\author{
Kalle KUUSK, Targo KALAMEES, Siim LINK, Simo ILOMETS, Alo MIKOLA \\ Tallinn University of Technology, Ehitajate tee 5, 19086 Tallinn, Estonia
}

Received 06 Mar 2014; accepted 08 Jul 2014

\begin{abstract}
The paper presents a case study analysis of low-budget renovation of a typical concrete large-panel apartment building. Focus is on the measurements and analyses of energy consumption, indoor climate, $\mathrm{CO}_{2}$ concentration, air leakage rate, thermal transmittance of thermal bridges, and thermal transmittance of the building envelope before and after the renovation. Results indicate that the renovation project was generally successful, with delivered energy need decreasing by $40 \%$ and heating energy need decreasing by $50 \%$. However, some key problems need to be solved to achieve full energy efficiency potential of the renovation works. Those critical problems are the performance (thermal comfort, heat recovery) of ventilation systems, thermal bridges of external wall/window jamb and economic viability. Currently, a major renovation is not economically viable, therefore financial assistance to the apartment owners' associations is required to encourage them to undertake major renovations.
\end{abstract}

Keywords: major renovation, case study, energy performance, economic viability, large-panel apartment buildings.

\section{Introduction}

It is estimated (Economidou et al. 2011) that there is 25 billion $\mathrm{m}^{2}$ of useful floor space in the EU27, Switzerland and Norway. Residential buildings account for $75 \%$ of the total building stock. A substantial share of the buildings in Europe is older than 50 years. Data on typical heating consumption levels of the existing buildings by age show that the largest energy saving potential is associated with older buildings where in some cases buildings from the 1960s are worse than buildings from earlier decades. The impact of poorly insulated 1960s buildings on the building stock energy consumption was amplified by the large boom in construction in 1961-1990 when the housing stock more than doubled. A study conducted in Vilnius showed that relative heat consumption data in the prefabricated concrete large-panel apartment buildings vary more in the 1960s than in the 1970s, which indicates an increase in the quality of construction works as designing and building crews gained more experience (Juodis et al. 2009). Retrofitting of the existing housing stock is crucial as the environmental impact from new buildings is negligible compared to the impact from existing buildings (Uihlein, Eder 2010).

At the European level, it has been found that countries have very different potentials for energy savings, depending on the size and condition of the housing stock. In total, $88 \mathrm{TWh}$ of heating energy could be saved annually in single family houses by the year 2020 and $58 \mathrm{TWh}$ in apartment buildings, totalling $146 \mathrm{TWh}$ of heating energy annually (Tuominen et al. 2012). The same study also pointed out the problem that energy efficiency improvements are a low priority for consumers. This is a major obstacle for achieving the maximum energy savings possible in retrofitting as the extent and selection of retrofitting measures depend mainly on the choices of inhabitants. Studies (Uihlein, Eder 2010) have shown that it is reasonable to ensure that at refurbishment in any case the best energy efficiency level possible is installed, not only for major renovations, but also for individual building elements. This is even more important as the residential building stock shows high inertia due to low stock turnover compared to other consumer goods such as household appliances or cars. Pilot renovation projects are helpful for inhabitants in their choices of retrofitting measures. Although the pilot projects generally involve one specific building, the general principles are transferable to other building types. This is especially true in Eastern Europe, where after the Second World War similar construction solutions were used in different countries. A survey of apartment buildings in Moscow concluded that the analysis of buildings is eased by the fact that there are only a few building types. On the other hand, in reality the used materials and their parameters can vary significantly also within the same building series. As the energy per-

Corresponding author: Kalle Kuusk

E-mail:kalle.kuusk@ttu.ee 
formances of the different building types do not differ significantly, an adequate analysis can be made even by using only one building type (Paiho et al. 2013).

To encourage apartment owners' associations to undertake major renovation, a pilot energy-renovation project "Healthy and Economical Home" was started in spring 2010 in cooperation with two financing institutions, the ministry, an energy company, the local municipality and a university. The global purpose was to carry out an example renovation of a typical apartment building to test renovation measures and to motivate occupants to renovate their apartment buildings. This study provides reliable data not available so far due to a small number of renovation cases where energy usage is measured before and after the renovation. The aim is to present a detailed overview of the plans and results of the apartment building energy renovation.

\section{Methods}

\subsection{Analysed building}

In the spring of 2010 an apartment building composed of prefabricated concrete large panel elements (type project I-464) (Table 1, Fig. 1) was selected as the pilot object.

The type of construction shown in Figure 1 was very typical in Eastern Europe during the period 1961-1990.
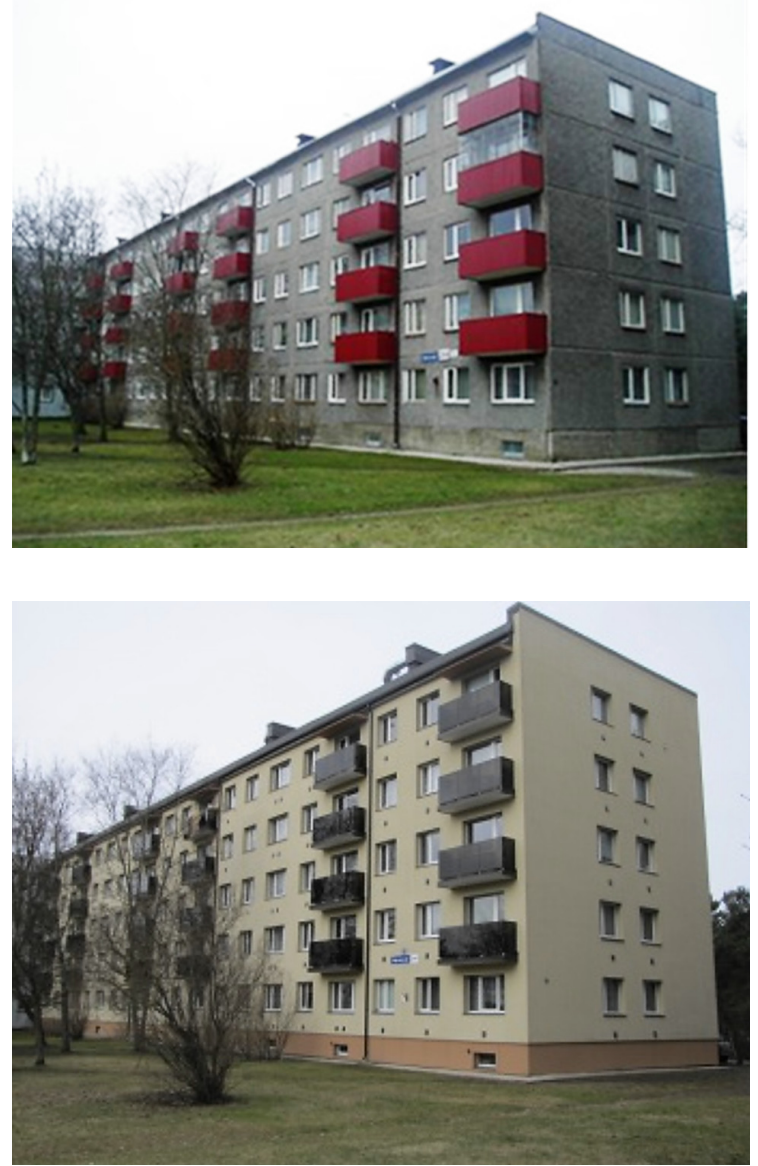

Fig. 1. Picture of the building before (top) and after (bottom)
Table 1. Characteristics of the renovated building

\begin{tabular}{l|l}
\hline Construction year & 1966 \\
\hline Number of floors & 5 \\
\hline Net area, $\mathrm{m}^{2}$ & 3519 \\
\hline Heated area, $\mathrm{m}^{2}$ & 2968 \\
\hline Number of apartments & 60 \\
\hline $\begin{array}{l}\text { Compactness: Building envelope, } \\
\mathrm{m}^{2} / \text { volume } \mathrm{m}^{3}, \mathrm{~m}^{-1}\end{array}$ & 0.35 \\
\hline
\end{tabular}

For example, 2 million $\mathrm{m}^{2}$ of prefabricated concrete large panel apartment buildings were built during that period in Estonia (Kalamees et al. 2009) and 4.7 million $\mathrm{m}^{2}$ in Vilnius, Lithuania (Ignatavičius et al. 2007).

\subsection{Measurements}

Measurements concentrated on the indoor climate and energy performance before and after renovation:

- the use of heat and electricity was determined on a monthly basis;

- the indoor temperature and relative humidity $(\mathrm{RH})$ were measured with data loggers at $1 \mathrm{~h}$ intervals over a two year period in four apartments;

- indoor $\mathrm{CO}_{2}$ concentration was measured during a two week period in three bedrooms as an indicator of the indoor air quality;

- air leakages of the building envelope were measured with the standardised fan pressurisation method (EN 13829 2000).

\subsection{Criteria for renovation solutions}

The main goals were set before the designing started in 2010. The aims for the renovation were:

- to select renovation solutions that offer maximum repeatability for similar apartment buildings;

- to achieve the same energy efficiency (expressed as Primary Energy, PE) as are the requirements for new apartment buildings: $\mathrm{PE} \leq 150 \mathrm{kWh} /\left(\mathrm{m}^{2} \cdot \mathrm{a}\right)$;

- to decrease heating energy use by $>50 \%$;

- to reach the indoor climate category II (EN 15251 2007);

- cost of renovation works $\leq 160 € /$ heated $\mathrm{m}^{2}$;

- air leakage rate $q_{50}<3 \mathrm{~m}^{3} /\left(\mathrm{h} \cdot \mathrm{m}^{2}\right)$;

- to extend service life of the building after the renovation by 50 years;

- to receive apartment owners' association's approval of the designed renovation solutions.

PE usage for different renovation solutions was calculated according to a unified calculation methodology and with the standard usage (Estonian Government's Ordinance No. 258 2007). PE takes into account the use of primary energy (space heating, ventilation, domestic hot water, all electricity (including lighting and appliances (plug loads)) and environmental impact according to the energy source, with weighting factors: district heating 0.9; fossil fuel (gas, coal etc.) 1.0; electricity 1.5 (2.0 
Table 2. Renovation measures and costs

\begin{tabular}{|c|c|c|c|c|}
\hline Renovation measures & $\begin{array}{l}\text { Thermal transmittance } \\
\text { of building envelope } U \text {, } \\
\mathrm{W} /\left(\mathrm{m}^{2} \cdot \mathrm{K}\right)\end{array}$ & $\begin{array}{l}\text { Linear thermal } \\
\text { transmittance of thermal } \\
\text { bridges } \Psi, \mathrm{W} /(\mathrm{m} \cdot \mathrm{K})\end{array}$ & Cost, $€$ & $\begin{array}{l}\text { Cost, } € / \\
\text { heated } \mathrm{m}^{2}\end{array}$ \\
\hline \multicolumn{5}{|l|}{ Roof } \\
\hline $\begin{array}{l}\mathrm{R}_{1}: \quad 40 \mathrm{~cm} \text { cellulose loose-fill insulation inside the } \\
\text { roof structure }\end{array}$ & $U_{\text {roof }}=0.23$ & $\Psi_{\text {eave }}=0.24$ & 16000 & 5 \\
\hline $\mathrm{R}_{2}: \quad 30 \mathrm{~cm}$ EPS above the roof & $U_{\text {roof }}=0.11$ & $\Psi_{\text {eave }}=0.29$ & 32000 & 11 \\
\hline \multicolumn{5}{|l|}{ External wall } \\
\hline $\mathrm{E}_{1}: \quad 15 \mathrm{~cm}$ EPS & $U_{\text {wall }}=0.21$ & \multirow{3}{*}{$\begin{array}{l}\Psi_{\text {wall } / \text { wall }}=0.16 \\
\Psi_{\text {wall } / \text { balcony }}=0.44\end{array}$} & 73000 & 25 \\
\hline $\mathrm{E}_{2}: \quad 15 \mathrm{~cm}$ GE-EPS & $U_{\text {wall }}=0.17$ & & 76000 & 26 \\
\hline $\mathrm{E}_{3}: \quad 20 \mathrm{~cm} \mathrm{EPS}$ & $U_{\text {wall }}=0.16$ & & 78000 & 26 \\
\hline \multicolumn{5}{|l|}{ Windows } \\
\hline \multirow{2}{*}{$\begin{aligned} \mathrm{W}_{1} \text { : } & \text { replacing old windows } \\
& (33 \% \text { from all windows }) \\
& \text { removing the concrete layer around the } \\
& \text { windows to add insulation to window jamb's }\end{aligned}$} & $\begin{array}{l}U_{\text {old window }}=1.8 \\
U_{\text {new window }}=1.1\end{array}$ & $\Psi_{\text {wall } / \text { window }}=0.08$ & 21000 & 7 \\
\hline & & & 7000 & 2 \\
\hline $\mathrm{W}_{2}:$ replacing of all windows & $U_{\text {new window }}=0.9$ & $\Psi_{\text {wall } / \text { window }}=0.04$ & 112000 & 38 \\
\hline \multicolumn{5}{|l|}{ Basement wall } \\
\hline $10 \mathrm{~cm}$ EPS & $U_{\text {basement wall }}=0.36$ & & 7000 & 2 \\
\hline \multicolumn{5}{|l|}{ Balconies } \\
\hline repairing of balconies slabs and new railings & & & 32000 & 11 \\
\hline \multicolumn{5}{|l|}{ Heating system } \\
\hline new 2-pipe system with thermostats & & & 96000 & 32 \\
\hline \multicolumn{5}{|l|}{ Ventilation system } \\
\hline $\begin{array}{l}\text { central exhaust system with heat recovery with } \\
\text { exhaust air heat pump }\end{array}$ & & & 83000 & 28 \\
\hline
\end{tabular}

since 2013) (Estonian Government's Ordinance No. 68 2012).

The renovation measures analysed are shown in Table 2 . The potential cost of the renovation was calculated on the basis of the estimates of the construction company.

Heat recovery from the ventilation system was solved with an exhaust air heat pump (Fig. 2) with an estimated annual average coefficient of performance $\mathrm{COP}=3.0$. Supply air enters through fresh air radiators being filtered and heated at the same time. Extract air

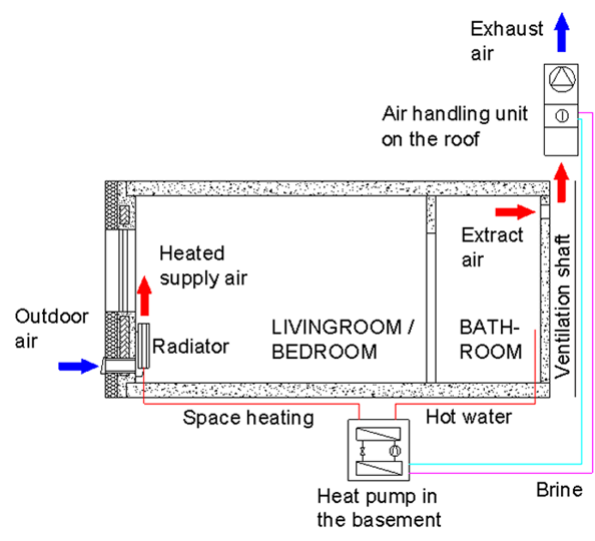

Fig. 2. The principle of heat recovery of centralised exhaust ventilation system with exhaust air heat pump moves through ventilation shafts to an air handling unit cooling coil where heat is transferred with a brine loop to water to a water heat pump. The heat pump provides heat to the domestic hot water and the space heating system.

\subsection{Simulations}

Energy performance of potential renovation solutions was simulated using the energy and indoor climate simulation program IDA Indoor Climate and Energy 4.5 (IDA-ICE 2014). This software is validated (Kropf, Zweifel 2001; Moinard, Guyon 2000; Travesi et al. 2001) and used for scientific modelling in research papers (Arumägi, Kalamees 2014; Kuusk et al. 2014). Software allows the modelling of a multi-zone building, internal and solar loads, outdoor climate, HVAC systems, dynamic simulation of heat transfer and air flows.

The building was simulated as a 21-zone (Fig. 3) half building model because the building is symmetrical. Different zones were each apartment, staircase and a cellar. The second, third and fourth floor as identical were simulated by one floor and the results were multiplied.

Internal heat gains in the renovation measures were as follows:

- inhabitants: $15.8 \mathrm{kWh} /\left(\mathrm{m}^{2} \cdot \mathrm{a}\right)$. Heat from inhabitants was counted from $3.0 \mathrm{~W} / \mathrm{m}^{2}$ and $80 \mathrm{~W} /$ person using the ISO 7730:2005 (2009) standard (1.2 met, 0.7 clo); 


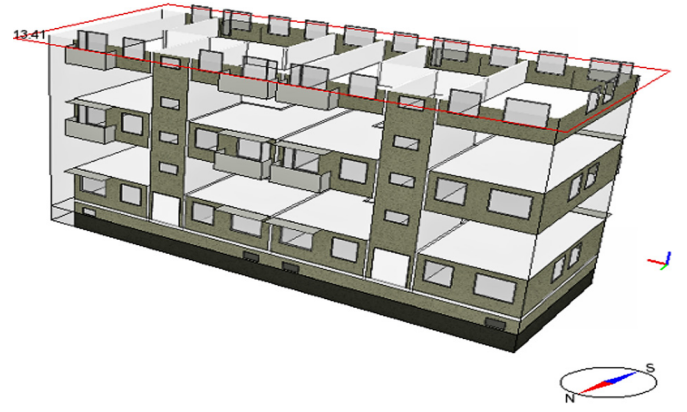

Fig. 3. Simulation model in IDA-ICE (2014) of the studied building

- appliances, equipment: $15.8 \mathrm{kWh} /\left(\mathrm{m}^{2} \cdot \mathrm{a}\right)$. Heat from appliances and equipment was counted using $3.0 \mathrm{~W} / \mathrm{m}^{2}$ and the usage rate was 0.6 ;

- lighting: $7.0 \mathrm{kWh} /\left(\mathrm{m}^{2} \cdot \mathrm{a}\right)$. Heat from lighting was counted using $8 \mathrm{~W} / \mathrm{m}^{2}$ and the usage rate was 0.1 .

Ventilation airflow was $1.0 \mathrm{l} / \mathrm{s}$ for a bedroom and a living room $\mathrm{m}^{2}$ for renovation packages representing indoor climate category II (EN 15251 2007). The use of domestic hot water (DHW) is $45 \mathrm{l}$ / (pers. $\times$ day). The number of occupants per apartment was estimated to be the number of bedrooms +1 .

An Estonian Test Reference Year (Kalamees, Kurnitski 2006) was used for outdoor climate conditions (design outdoor temperature for heating $-21{ }^{\circ} \mathrm{C}$, heating degree days at $t_{i} 17^{\circ} \mathrm{C}: 4160{ }^{\circ} \mathrm{C} \cdot \mathrm{d}$ ).

\subsection{Renovation costs}

The potential cost of the renovation is shown in Table 2. Project partners supported the renovation with the following grants:

- local municipality grant for renovation loan selffinance (19 $173 €)$;

- renovation grant $35 \%$ of the cost of the energy efficiency works (124 $220 €$ );

- grant for the installation of the ventilation system with heat recovery (63911 $€$ );

- grant for the installation of individual space heating measuring system $(12000 €)$.

In addition to direct grants, the renovation loan interest rate for the pilot project was $1 \%$. The average interest rate for renovation loans in Estonia is 4\% (Fund KredEx 2014). Global cost calculations were made for two renovation cases: with grants and without grants. In the version without grants, the renovation loan interest was taken into account with the typical interest rate of $4 \%$. Maintenance fund payment before renovation was $0.3 €$ per apartment $\mathrm{m}^{2}$ and after renovation $0.1 €$ per apartment's $\mathrm{m}^{2}$.

Energy prices before the renovation were the starting point of our economic calculations. In 2010 energy prices were as follow: electricity $87 € / \mathrm{kWh}$, district heating $64 € / \mathrm{kWh}$ and natural gas $38 € / \mathrm{kWh}$. Energy prices escalation for electricity and natural gas is based on Statistics Estonia (2014) database. District heating price escalation is based on the data received from district the heating company. Average escalation in 2007-2013 for electricity and natural gas was $9 \%$ and for district heating $6 \%$.

\section{Results}

\subsection{Selection of renovation package}

The renovation packages analysed are shown in Table 3. Maximum repeatability criterion was fulfilled with the selection of the pilot object. Selected building type is widespread in Estonia, accounting for $48 \%$ of the total surface area of the prefabricated concrete large panel apartment buildings and $17 \%$ of the total surface area of all apartment buildings. All proposed renovation measures meets the renovation cost criterion (cost $<160 € /$ heated $\mathrm{m}^{2}$ ). A decision was made considering primary energy (PE) use. Only packages containing replacement of all windows met the set criterion $\mathrm{PE} \leq 150 \mathrm{kWh} /\left(\mathrm{m}^{2} \cdot \mathrm{a}\right)$. The selected package was $\mathrm{R}_{2} \mathrm{E}_{2} \mathrm{~W}_{1}$ (30 cm EPS above the roof, $15 \mathrm{~cm}$ GE-EPS on the external wall and replacing only old windows). Because before the renovation already $75 \%$ of windows had been replaced, it was decided to change only the remaining $25 \%$. The solution was selected because it is more comfortable from the point of view of inhabitants' living conditions during the renovation (less work inside the apartment) and prevented opposition by apartment owners who were against replacing already changed windows. The PE usage criterion was planned to be achieved with the usage of a heat pump with a higher COP than 3.0, as obtained in the estimated energy performance calculations.

Thermal transmittance of the building envelope and the linear thermal transmittance of thermal bridges before and after renovation are shown in Table 4.

Thermal transmittance of the external walls and of the roof was significantly reduced. Because renovation was done on a low budget, the usage of thicker layers of additional insulation on the external wall and the roof

Table 3. Analysed renovation packages (grey shaded is the realised renovation packages)

\begin{tabular}{llll}
\hline $\begin{array}{l}\text { Renovation } \\
\text { package* }\end{array}$ & $\begin{array}{l}\mathrm{PE}, \\
\mathrm{kWh} /\left(\mathrm{m}^{2} \cdot \mathrm{a}\right)\end{array}$ & Cost, $€$ & $\begin{array}{l}\text { Cost, } \\
€ / \text { heated } \mathrm{m}^{2}\end{array}$ \\
\hline $\mathrm{R}_{1} \mathrm{E}_{1} \mathrm{~W}_{1}$ & 155 & 334000 & 113 \\
$\mathrm{R}_{1} \mathrm{E}_{2} \mathrm{~W}_{1}$ & 154 & 338000 & 114 \\
$\mathrm{R}_{1} \mathrm{E}_{3} \mathrm{~W}_{1}$ & 153 & 340000 & 115 \\
$\mathrm{R}_{1} \mathrm{E}_{1} \mathrm{~W}_{2}$ & 148 & 437000 & 147 \\
$\mathrm{R}_{1} \mathrm{E}_{2} \mathrm{~W}_{2}$ & 147 & 441000 & 149 \\
$\mathrm{R}_{1} \mathrm{E}_{3} \mathrm{~W}_{2}$ & 146 & 443000 & 149 \\
$\mathrm{R}_{2} \mathrm{E}_{1} \mathrm{~W}_{1}$ & 153 & 350000 & 118 \\
$\mathrm{R}_{2} \mathrm{E}_{2} \mathrm{~W}_{1}$ & 151 & 354000 & 119 \\
$\mathrm{R}_{2} \mathrm{E}_{3} \mathrm{~W}_{1}$ & 151 & 355000 & 120 \\
$\mathrm{R}_{2} \mathrm{E}_{1} \mathrm{~W}_{2}$ & 145 & 453000 & 153 \\
$\mathrm{R}_{2} \mathrm{E}_{2} \mathrm{~W}_{2}$ & 144 & 457000 & 154 \\
$\mathrm{R}_{2} \mathrm{E}_{3} \mathrm{~W}_{2}$ & 144 & 459000 & 155 \\
\hline
\end{tabular}


Table 4. Thermal properties of the building envelope

\begin{tabular}{l|l|l}
\hline $\begin{array}{l}\text { Thermal transmittance of building } \\
\text { envelope } \mathrm{U}, \mathrm{W} /\left(\mathrm{m}^{2} \cdot \mathrm{K}\right)\end{array}$ & $\begin{array}{l}\text { Before } \\
\text { renovation }\end{array}$ & $\begin{array}{l}\text { After } \\
\text { renovation }\end{array}$ \\
\hline walls $U_{\text {wall }}$ & 0.90 & 0.17 \\
roof $U_{\text {roof }}$ & 0.70 & 0.11 \\
$\quad$ windows $U_{\text {window }}$ & 1.85 & 1.40 \\
$\begin{array}{l}\text { Linear thermal transmittance of } \\
\text { thermal bridges } \mathrm{Y}, \mathrm{W} /(\mathrm{m} \cdot \mathrm{K})\end{array}$ & & \\
\hline $\begin{array}{l}\text { external wall/external wall } \\
\text { external wall/internal wall }\end{array}$ & 0.70 & 0.15 \\
$\quad$ external wall/internal floor & 0.30 & 0.01 \\
external wall/basement ceiling & 0.50 & 0.01 \\
external wall/roof & 0.50 & 0.06 \\
external wall/window & 0.55 & 0.20 \\
$\quad$ external wall/balcony floor & 0.13 & 0.20 \\
\hline Air leakage rate $q_{50}, \mathrm{~m}^{3} /\left(\mathrm{h} \cdot \mathrm{m}^{2}\right)$ & 0.20 & 0.45 \\
\hline
\end{tabular}

was withdrawn. The largest unused potential of the reduction of thermal transmittance of the building envelope is in the replacement of windows. The full potential was not realised because not all the windows were replaced. Stairwell doors were not replaced during renovation. Given a very small share of the total building envelope area, not changing the existing stairwell doors is not relevant in terms of overall energy usage.

Linear thermal transmittance of thermal bridges in the external wall/internal wall and the external wall/internal floor junctions was practically removed. Linear thermal transmittance of thermal bridges in the external wall/external wall and the external wall/roof junctions was significantly reduced. Problem areas are the external wall/balcony floor junctions and the external wall/ window where the linear thermal transmittance of thermal bridges increased after renovation because windows stayed in their original place and were not moved into the insulation layer.

\subsection{Energy performance}

The usage of primary energy decreased by $20 \%$ : before the renovation it was $212 \mathrm{kWh} /\left(\mathrm{m}^{2} \cdot \mathrm{a}\right)$ and after renovation $168 \mathrm{kWh} /\left(\mathrm{m}^{2} \cdot \mathrm{a}\right)$. Figure 4 shows measured delivered energy usage before the renovation $\left(216 \mathrm{kWh} /\left(\mathrm{m}^{2} \cdot \mathrm{a}\right)\right)$, calculated expected delivered energy usage $(103 \mathrm{kWh} /$ $\left(\mathrm{m}^{2} \cdot \mathrm{a}\right)$ ), calculated expected heat pump (HP) heating energy production, measured delivered energy usage after renovation $\left(132 \mathrm{kWh} /\left(\mathrm{m}^{2} \cdot \mathrm{a}\right)\right)$, and measured heat pump heating energy production.

Delivered space heating need decreased by $49 \%$, delivered energy need for heating domestic hot water decreased by $40 \%$. The main reason for failure to achieve calculated energy performance was the heat production of the exhaust air heat pump. It was estimated that the heat pump would produce $260 \mathrm{MWh}$ annually and the heat pump would cover total energy need for heating domestic

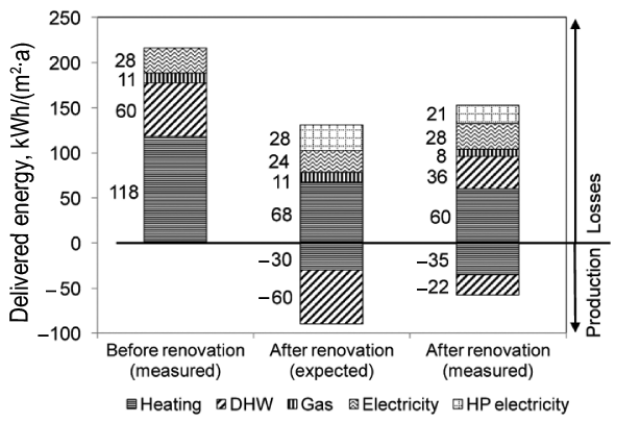

Fig. 4. Energy performance before and after renovation

hot water. Actual production was $170 \mathrm{MWh}$ and the heat pump covered $40 \%$ of the energy need for domestic hot water heating.

\subsection{Indoor climate}

There was a significant difference in the temperature measurement results before and after the renovation. Indoor temperature measurement results in accordance with indoor climate categories (EN 152512007 ) are shown in Figure 5. Before renovation apartments were overheated, especially during cold periods. There was no significant difference in the RH or moisture excess before and after renovation. The RH was correlated with the outdoor air temperature and dropped below $20 \%$ during the coldest period.

$\mathrm{CO}_{2}$ concentration was measured in three apartments in a two-week period. Measurement results are shown for night time (23:00-07:00) before and after the renovation, see Figure 6. Results indicate that the $\mathrm{CO}_{2}$ levels in the bedrooms decreased but the indoor climate criterion set before the renovation was not achieved.

Before the renovation, the bedroom indoor air $\mathrm{CO}_{2}$ concentration met the indoor climate class II requirements $20 \%$ of the time and the class III requirements $53 \%$ of the time. After the renovation, the $\mathrm{CO}_{2}$ concentration met the class II requirements $66 \%$ of the time and the class III requirements $97 \%$ of the time.

Airtightness of the building envelope before and after the renovation was measured in eight apartments. Before renovation three apartments had old 2-frame wooden

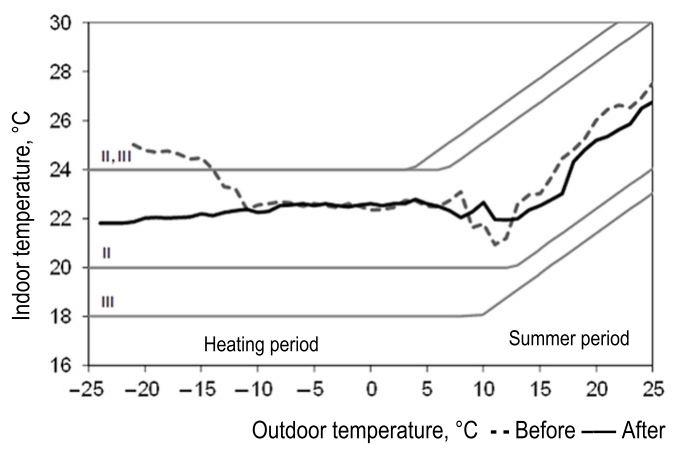

Fig. 5. Measurement results of indoor air temperature depending on the outdoor air temperature before and after the renovation 


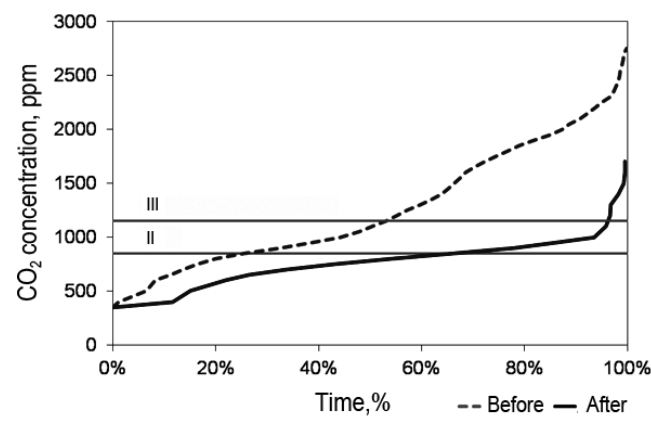

Fig. 6. Measurement results of indoor $\mathrm{CO}_{2}$ concentration before and after the renovation

windows that were a part of a passive stack ventilation system. During renovation all old windows were replaced with new PVC 3-layer glass windows with one frame. The results of airtightness measurements are shown in Figure 7.

Airtightness of the building envelope improved only in apartments where windows were replaced during renovation, decrease of average air leakage rate was $26 \%$. With existing PVC windows, average air leakage rate increased by $18 \%$. Only one apartment out of the measured eight met the set post-renovation airtightness criterion of air leakage rate $q_{50}<3 \mathrm{~m} /\left(\mathrm{h} \cdot \mathrm{m}^{2}\right)$.

\subsection{Renovation costs}

Total cost of renovation works met the criterion set before renovation $\left(\leq 160 € /\right.$ heated $\left.\mathrm{m}^{2}\right)$ but actual costs were $28 \%$ higher than planned. Estimates were that renovation cost would be $119 € /$ heated $\mathrm{m}^{2}$, actual costs were $152 € /$ heated $\mathrm{m}^{2}$ (Table 3, Table 5).

The main reason why the predictions were inaccurate was the cost of external wall additional insulation, which was $62 \%$ higher than estimated. One of the reasons is the fact that the assessments of the construction costs were made almost two years before the renovation, and the costs had risen in the meantime.

Annual costs per apartment $\mathrm{m}^{2}$ without renovation and with renovation are shown in Figure 8. Costs are calculated as average for a loan period (20 years) and with the energy price escalation.

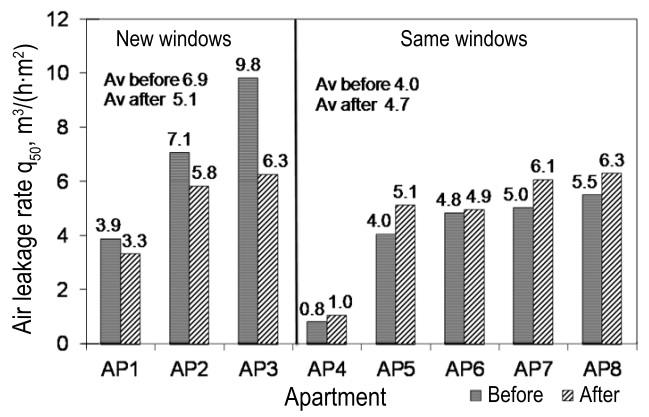

Fig. 7. Results of airtightness before and after renovation with wooden windows that were replaced (left) and existing PVC windows (right)
Table 5. Expected and actual renovation measure

\begin{tabular}{|c|c|c|c|c|}
\hline \multirow[b]{2}{*}{$\begin{array}{l}\text { Renovation } \\
\text { measure }\end{array}$} & \multicolumn{2}{|c|}{ Expected cost } & \multicolumn{2}{|c|}{ Actual cost } \\
\hline & $€$ & $\begin{array}{c}€ / \text { heated } \\
\mathrm{m}^{2}\end{array}$ & $€$ & $\begin{array}{c}€ / \text { heated } \\
\mathrm{m}^{2}\end{array}$ \\
\hline Insulation of roof & 32000 & 11 & 40700 & 14 \\
\hline $\begin{array}{l}\text { Insulation of } \\
\text { external walls } \\
\text { (with foundation } \\
\text { walls) }\end{array}$ & 83000 & 28 & 132500 & 45 \\
\hline $\begin{array}{l}\text { Replacement of } \\
\text { old windows }\end{array}$ & 21000 & 7 & 16500 & 6 \\
\hline $\begin{array}{l}\text { Removing the } \\
\text { concrete layer } \\
\text { around the } \\
\text { windows }\end{array}$ & 7000 & 2 & - & - \\
\hline $\begin{array}{l}\text { Renovation of } \\
\text { balconies }\end{array}$ & 32000 & 11 & 48300 & 16 \\
\hline $\begin{array}{l}\text { Renovation of } \\
\text { heating system }\end{array}$ & 96000 & 32 & 100000 & 34 \\
\hline $\begin{array}{l}\text { Renovation } \\
\text { of ventilation } \\
\text { system }\end{array}$ & 83000 & 28 & 100000 & 34 \\
\hline $\begin{array}{l}\text { Installation } \\
\text { of individual } \\
\text { heating } \\
\text { measuring system }\end{array}$ & - & - & 12000 & 4 \\
\hline Total & 354000 & 119 & 450000 & 152 \\
\hline
\end{tabular}

Results show that the current pilot project with grants was economically reasonable for inhabitants and annual total costs per apartment $\mathrm{m}^{2}$ were $3.4 €$ lower than without renovation. If the same renovation works are done without grants, then the annual costs per apartment $\mathrm{m}^{2}$ would be $4.1 €$ higher than without renovation. Therefore, financial assistance to apartment owners' associations is required to perform major renovation.

\section{Discussion}

PE consumption was higher than estimated. The main reason is the performance of the heat recovery system with the exhaust air heat pump. It was estimated that the heat pump would cover total energy need for heat-

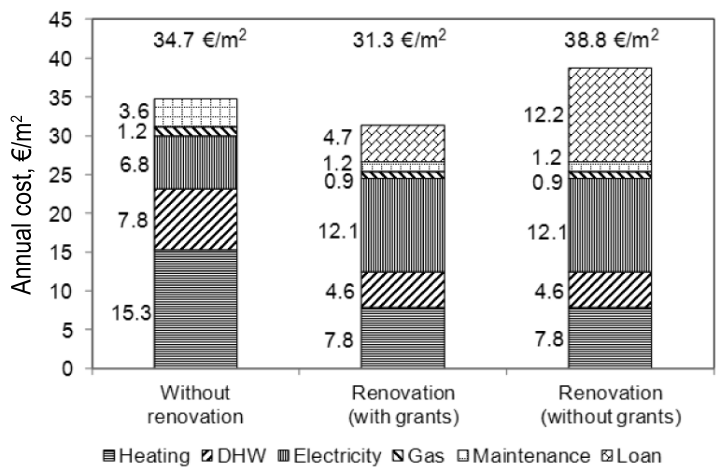

Fig. 8. Annual costs per apartment $\mathrm{m}^{2}$ without renovation and with renovation 
ing domestic hot water. Measurements after renovation showed that the heat pump covered $40 \%$ of the energy need for domestic hot water heating. Identification of the exact causes requires further investigation of the system, however, the system did not started working as expected. That kind of system was a new solution for renovation of apartment buildings in Estonia. Previous studies about retrofitting have concluded that with the use of innovative systems, they will probably not work exactly as predicted (Branco et al. 2004). Subsequent research in Estonia (Kõiv et al. 2012) has shown that the estimation of the coefficient of the performance of an exhaust air heat pump was correct $(\mathrm{COP}=3.0)$.

One of the reasons for failure to achieve the PE usage criterion was that thermal bridges were not eliminated in the external wall/window junction. Calculations showed that in the current case the heat loss through thermal bridges around the windows and the heat loss through additionally insulated external walls are at a similar scale (Ilomets, Kalamees 2013). In energy calculations it was estimated that the linear thermal transmittance of thermal bridges in the external wall/window junction would be diminished. The reality was that the linear thermal transmittance of thermal bridges in the external wall/window junction increased because not all the windows were replaced and therefore not all kept their original position. That decision was made by the apartment owners' association who had to approve designed renovation solutions. Previous studies have shown that the opinion of the decision maker has a major impact on the results and owner's care mainly about having a short payback period (Medineckiené, Björk 2011). The apartment owners found it too expensive to replace all windows and move them into the insulation layer. The back-up plan to place additional insulation to the window jamb was not possible in the extent that was planned. Removing part of the concrete layer surrounding the windows and replacing that with a layer of insulation was not possible. Therefore it was impossible to install a sufficient layer of insulation to the window jambs, but the thermal bridge on the external wall/window junction is very sensitive to the thickness of insulation on a window's jamb (Ilomets, Kalamees 2013).

Regarding to the PE usage criterion, the problem was that airtightness of the building envelope was not improved. In the energy calculations, it was estimated that the air leakage rate after renovation would be $q_{50}<$ $3 \mathrm{~m} /\left(\mathrm{h} \cdot \mathrm{m}^{2}\right)$. The actual air leakage rate after renovation was $q_{50}=5 \mathrm{~m}^{3} /\left(\mathrm{h} \cdot \mathrm{m}^{2}\right)$. Measurements after the renovation showed that airtightness improved only in the apartments where windows were replaced, which was the expected result. As studies have shown, replacing of old draughty windows with modern sealed windows will reduce the background infiltration rate by the order of 0.1 ach to 0.3 ach (Ridley et al. 2003). If windows were not replaced, the air leakage rate would actually increase. That was probably caused by new openings for ventilation in- lets behind the fresh air radiators. There was a gap around the air inlet sleeve and the external wall that is difficult to tighten.

Measurements of the indoor temperature before and after the renovation show improvements due to better adjustment of a new heating system. Overheating is avoided during colder periods. The problem is that considering the $\mathrm{CO}_{2}$ concentration, the indoor climate category II criterion was not achieved. After the renovation, the bedroom indoor air $\mathrm{CO}_{2}$ concentration met indoor climate class II requirements only for $66 \%$ of the measurements time. The main reason for that is the reduction of the airflow in the ventilation system by the inhabitants. The design airflow for the ventilation system was $2.1 \mathrm{~m}^{3} / \mathrm{s}$. After renovation the measured airflow was $1.43 \mathrm{~m}^{3} / \mathrm{s}$. Fan speeds in two air handling units were reduced by the inhabitants because of the problems with thermal comfort caused by fresh air radiators. In the spring and the autumn, the air that enters the radiator does not heat up sufficiently. The reason lies in the fact that an insulated building does not need substantial heating in spring and autumn and radiators are at a low temperature and the entering cold air does not heat up, causing thermal discomfort. Another problem which is associated with renovation of the ventilation system is the airtightness of the ventilation shafts. Existing ventilation shafts were not airtight and new ventilation ducts were placed in the existing air shafts to ensure the required airtightness of ventilation ducts. Installation of new ducts was not always successful since existing shafts joints were not perfectly aligned. In some shafts it was not possible to insert the new duct to the entire length of the existing shaft. So the airtightness of all the exhaust ducts was not ensured and therefore it is difficult to ensure design exhaust airflow from all apartments.

From an economic point of view, the pilot project was successful. Apartment owners' annual costs were reduced and the cost of renovation works criterion was fulfilled. Annual cost reduction was achieved due to grants for renovation works. Without the grants, the annual cost after the major renovation would be higher for apartment owners and that would make it difficult for apartment owners' association to make a decision for major renovation as one of the main priorities for apartment owners is a short payback period (Medineckiené, Björk 2011). Such an approach is sufficient for choosing renovation solutions. The effectiveness of retrofitting an apartment building should be evaluated from various perspectives: energy conservation, improved state of the building structures, prolonged lifetime of the building, and an increase in market value taken into account (Zavadskas et al. 2008). Some studies have shown that renovated buildings are less sensitive to fluctuations in the heat price than those where renovation is not performed. Despite constant loan payments, renovated buildings will be in a better position in the sense of the overall payment rather than non-renovated buildings (Biekša et al. 2011). This 
study showed that although the impact of the heat price on the overall payment is significantly diminished after the renovation, the overall payment would be higher than with non-renovated buildings if no grants are available for apartment owners' associations. The reason is that existing apartment buildings have natural ventilation systems which need replacement with mechanical ventilation system with heat recovery to ensure the indoor climate quality. Fans and, depending on the solution, exhaust air heat pumps or heating coils in apartment based air handling units need electricity, therefore overall electricity consumption of the apartment buildings increases. Adding a loan payment and considering the fact that electricity is significantly more expensive than district heating, the reduction of the heating energy need does not cover the loan payments and increased electricity bills. Grants for renovation works are required to guide inhabitants to choose a better indoor climate and make the decision to install a proper ventilation system which seems costly at first sight.

\section{Conclusions}

The renovation project was generally successful, but some of the goals set before the renovations were not achieved. The construction cost target was fulfilled, but the energy consumption and indoor climate goals remained unfulfilled. Success of the renovation project depends on the detailed design of the renovation solutions and ability to direct the apartment owners to make the right choices. Although at large the renovation was successful, as the heating costs were reduced, indoor climate and aesthetics improved, there were some key issues that led to failure to achieve some of the targets set before renovation:

- thermal comfort of the ventilation system needs to be improved. Otherwise inhabitants will block the ventilation system work and the designed indoor climate is not achieved;

- thorough information and explanation for apartment owners is required to encourage them to make decisions that may seem costly at first sight, but are required to achieve the full energy efficiency potential of renovation works.

Overlooking specific problems encountered in this renovation project, it can be concluded that with major renovation:

- the energy efficiency levels of new apartment buildings are achievable;

- the financial assistance to apartment owners' associations is required to perform major renovation.

\section{Acknowledgements}

This work was supported by institutional research funding IUT1-15 "Nearly-zero energy solutions and their implementation on deep renovation of buildings" of the Estonian Ministry of Education and Research and by the European Union through the European Regional Development Fund (project 3.2.0801.11-0035 "Reducing the environmental impact of buildings through improvements of energy performance").

\section{References}

Arumägi, E.; Kalamees, T. 2014. Analysis of energy economic renovation for historic wooden apartment buildings in cold climates, Applied Energy 115: 540-548.

http://dx.doi.org/10.1016/j.apenergy.2013.10.041

Branco, G.; Lachal, B.; Gallinelli, P.; Weber, W. 2004. Predicted versus observed heat consumption of a low energy multifamily complex in Switzerland based on long-term experimental data, Energy and Buildings 36(6): 543-555. http://dx.doi.org/10.1016/j.enbuild.2004.01.028

Biekša, D.; Šiupšinskas, G.; Martinaitis, V.; Jaraminienè, E. 2011. Energy efficiency challenges in multi-apartment building renovation in Lithuania, Journal of Civil Engineering and Management 17(4): 467-475. http://dx.doi.org/10.3846/13923730.2011.622408

Economidou, M.; Atanasiu, B.; Despret, C.; Maio, J.; Nolte, I.; Rapf, O. 2011. European buildings under the microscope: A country-by-country review of the energy performance of European buildings. Buildings Performance Institute, Brussels. 129 p.

EN 15251 Indoor environmental input parameters for design and assessment of energy performance of buildings-addressing indoor air quality, thermal environment, lighting and acoustics and National Appendix. Comité Européen de Normalisation (CEN), Brussels, 2007. 52 p.

EN 13829 Thermal performance of building-Determination of air permeability of buildings - Fan pressurization method (ISO 9972:1996, modified). Comité Européen de Normalisation (CEN), Brussels, 2000. 24 p.

Estonian Government's Ordinance No. 258. Minimum requirements for energy performance of buildings. RT I, 2007, 72,445 .

Estonian Government's Ordinance No. 68. Minimum requirements for energy performance of buildings. RT I, 05.09.2012, 4, 2012.

Fund KredEx. 2014 [online], [cited 10 April 2014]. Available from Internet: http://www.kredex.ee/kredexist/uudised/ kredex-jatkab-renoveerimislaenu-pakkumist-korterelamutele/ (in Estonian).

IDA-ICE. 2014. IDA Indoor Climate and Energy 4.5 [online], [cited 10 April 2014]. Available from Internet: http://www.equa-solutions.co.uk/

Ignatavičius, Č.; Zavadskas, E.; Ustinovičius, L. 2007. Modernization of large-panel houses in Vilnius, in Proc. of the $9^{\text {th }}$ International Conference of Modern Building Materials, Structures and Techniques, 16-18 May 2007, Vilnius, Lithuania. 258-264.

Ilomets, S.; Kalamees, T. 2013. Case-study analysis on hygrothermal performance of ETICS on concrete wall after low-budget energy-renovation, in Proc. of XII International Conference on Performance of Exterior Envelopes of Whole Buildings, 1-5 December 2013, Florida, USA, ASHRAE. 14 p.

ISO 7730:2005 Ergonomics of the thermal environment - Analytical determination and interpretation of thermal comfort using calculation of the PMV and PPD indices and local thermal comfort criteria. International Organization for Standardization, Geneva, 2009. 52 p.

Juodis, E.; Jaraminiene, E.; Dudkiewicz, E. 2009. Inherent variability of heat consumption in residential buildings, Energy and Buildings 41(11): 1188-1194. http://dx.doi.org/10.1016/j.enbuild.2009.06.007

Kalamees, T.; Kurnitski, J. 2006. Estonian test reference year for energy calculations, in Proc. of the Estonian Academy of Science, Engineering 12: 40-58. 
Kalamees, T.; Õiger, K.; Kõiv, T.-A., et al. 2009. Technical condition and service life of Estonian apartment buildings, built with prefabricated concrete elements. Tallinn: Tallinn University of Technology. 54 p. (in Estonian).

Kropf, S.; Zweifel, G. 2001. Validation of the building simulation program IDA ICE according to CEN 13791 „, Thermal performance of buildings - calculation of internal temperatures of a room in summer without mechanical cooling - General criteria and validation procedures". Hochschule Technik+Architektur Luzern, Germany. HLK Engineering. 24 p.

Kuusk, K.; Kalamees, T.; Maivel, M. 2014. Cost effectiveness of energy performance improvements in Estonian brick apartment buildings, Energy and Buildings 77: 313-322. http://dx.doi.org/10.1016/j.enbuild.2014.03.026

Kõiv, T.-A.; Mikola, A.; Kuusk, K. 2012. Exhaust air heat pump heat recovery system for apartment buildings, in International Conference on Power and Energy Systems (ICPES 2012), 12-13 April 2012, Hong Kong, China. Information Engineering Research Institute. Lecture Notes in Information Technology 13: 250-255.

Medineckienė, M.; Björk, F. 2011. Owner preferences regarding renovation measures - the demonstration of using multicriteria decision making, Journal of Civil Engineering and Management 17(2): 284-295. http://dx.doi.org/10.3846/13923730.2011.582380

Moinard, S.; Guyon, G. 2000. Empirical validation of EDF, ETNA, and GENEC test-cell models. A Report of Task 22 Building Energy Analysis Tools. Project A.3 Empirical validation. International Energy Agency.
Paiho, S.; Hedman, Å.; Abdurafikov, R.; Hoang, H.; Sepponen, M.; Kouhia, I.; Meinander, M. 2013. Energy saving potentials of Moscow apartment buildings in residential districts. VTT Technology, Finland. 115 p.

Ridley, I.; Fox, J.; Oreszczyn, T.; Hong, S. H. 2003. The impact of replacement windows on air infiltration and indoor air quality in dwellings, The International Journal of Ventilation 1(3): 209-218.

Statistics Estonia. 2014. Database [online], [cited 10 April 2014]. Available from Internet: http://pub.stat.ee/pxweb.2001/I_Databas/Economy/07Energy/04Energy_efficiency indicators/04Energy efficiency indicators.asp

Travesi, J.; Maxwell, G.; Klaassen, C.; Holtz, M. 2001. Empirical validation of Iowa Energy Resource Station building energy analysis simulation models. A Report of Task 22, Subtask A, Building Energy Analysis Tools, Project A.1 Empirical Validation. International Energy Agency.

Tuominen, P.; Klobut, K.; Tolman, A.; Adjei, A.; Best-Waldhober, M. 2012. Energy savings potential in buildings and overcoming market barriers in member states of the European Union, Energy and Buildings 51: 48-55. http://dx.doi.org/10.1016/j.enbuild.2012.04.015

Uihlein, A.; Eder, P. 2010. Policy options towards an energy efficient residential building stock in the EU-27, Energy and Buildings 42(6): 791-798. http://dx.doi.org/10.1016/j.enbuild.2009.11.016

Zavadskas, E.; Raslanas, S.; Kaklauskas, A. 2008. The selection of effective retrofit scenarios for panel houses in urban neighbourhoods based on expected energy savings and increase in market value: the Vilnius case, Energy and Buildings 40(4): 573-587. http://dx.doi.org/10.1016/j.enbuild.2007.04.015

Kalle KUUSK. He is a researcher in Chair of Building Physics and Energy Efficiency in Tallinn University of Technology. His research fields are building's service systems, indoor climate and energy performance of buildings. Currently his is a $\mathrm{PhD}$ candidate with a topic "Renovation of apartment buildings toward nearly zero energy buildings".

Targo KALAMEES. He is the professor of Building Physics and head of Chair of Building Physics and Energy Efficiency in Tallinn University of Technology. His research fields are hygrothermal behaviour of buildings structures (computer simulations, laboratory experiments, field studies); boundary conditions for hygrothermal simulations and experiments; indoor climate and indoor air quality of residential-, office-, and heritage buildings; building's energy consumption and healthy building design; renovation/ retrofitting/reconstruction of buildings.

Siim LINK. He is a senior research scientist in Chair of Thermal Power Engineering in Tallinn University of Technology. His research fields are energy systems and thermochemical conversion of biomass.

Simo ILOMETS. He is a researcher/teaching assistant in Chair of Building Physics and Energy Efficiency in Tallinn University of Technology. His research fields are building physics, durability and renovation of buildings. He has MSc in civil engineering. Currently his is a $\mathrm{PhD}$ candidate with a topic "Probabilistic assessment of need for renovation and service life of Estonian apartment buildings".

Alo MIKOLA. He is a researcher/teaching assistant in Chair of Heating and Ventilation in Tallinn University of Technology. His research fields are building's service systems and indoor climate of buildings. Currently his is a PhD candidate with a topic "Indoor air quality in apartment buildings and improvement possibilities". 